Hydrol. Earth Syst. Sci. Discuss., 4, 2659-2681, 2007 www.hydrol-earth-syst-sci-discuss.net/4/2659/2007/

(C) Author(s) 2007. This work is licensed under a Creative Commons License.
Hydrology and Earth System Sciences Discussions

Papers published in Hydrology and Earth System Sciences Discussions are under open-access review for the journal Hydrology and Earth System Sciences

\title{
Multi-method geophysical measurements for soil science investigations in the vadose zone
}

\section{B. Weihnacht and F. Börner}

Dresden Groundwater Research Centre, Meraner Str. 10, 01217 Dresden, Germany

Received: 10 August 2007 - Accepted: 21 August 2007 - Published: 23 August 2007

Correspondence to: B. Weihnacht (bweihnacht@dgfz.de)

\section{HESSD}

4, 2659-2681, 2007

Geophysical proxies for soil science investigations

B. Weihnacht and

F. Börner

\section{Title Page}

Abstract

Conclusions

Tables

14

4

Back
Introduction

References

Figures

$\rightarrow$

Close
Full Screen / Esc

Printer-friendly Version

Interactive Discussion 


\section{Abstract}

We studied the changes of geophysical parameters on a soil wall of the testfield Grenzhof (University of Heidelberg). The unsaturated materials investigated range from coarse-grain gravel to sandy loam. Ground-penetrating radar, ultrasound transmission and complex conductivity measurements were applied as geophysical methods. The measured parameters were used to calculate soil parameters such as porosity, water content, density and grain surface area necessary to obtain geohydraulic parameters such as hydraulic conductivity, field capacity and retention parameters. Soil samples were taken and analysed regarding porosity, apparent density, true density and internal surface. The comparison between petrophysical data from the laboratory and from geophysical measurements showed good correlations for the majority of the data.

\section{Introduction}

Knowledge of the water content and the water flow in the vadose zone is essential for ground water protection, agriculture, waste management and river basin management. 15 However, investigations are complicated by high resolution desired in depth and noninvasive implementation.

Geophysical measurements can be conducted non-invasively from the surface or by using boreholes. They give in-situ values of comparatively large sample volumes. They are investigated under field condition and therefore undisturbed and left in their natural formation. Hence, important parameters such as compactness of the packing, temperature and water content are preserved. This is a major advantage compared to samples transported and afterwards analysed in the laboratory or TDR measurements, where probes have to be installed in the ground. Moreover, geophysical measurements can be applied quickly and on large scale.

25 Despite the numerous advantages one should note that parameters such as hydraulic conductivity, field capacity and retention parameters are not measured directly
HESSD

4, 2659-2681, 2007

Geophysical proxies for soil science investigations

B. Weihnacht and

F. Börner

Title Page

Abstract Introduction

Conclusions

Tables

References

Figures

14

4

Back

Close

Full Screen / Esc

Printer-friendly Version

Interactive Discussion 
for this approach. Consequently, the challenge lies in the development of geophysical and hydraulic models that allow for determination directly from the measured data, preferably without further calibration of soil samples (Fig. 1). Therefore, the general goal is a quantative interpretation of the geophysical data regarding hydraulic proper5 ties and the formulation of petrophysical models for each geophysical method applicable to a wide variety of soils under various conditions.

Petrophysical parameters obtained from geophysical measurements on a field scale are becoming more and more popular for environmental applications. Monitoring solute transport using electrical resistivity tomography has found broad application (e. $g$. 10 French et al., 2002, Kemna et al., 2002). Radar measurements are state-of-the-art for the determination of the water content and have been applied to a broad variety of tasks. Wollschläger et al. (2005) monitored the temporal changes of the volumetric soil water content on a testfield. A large tank filled with sandy soil was investigated by Lambot et al. (2004). Measurements on a lysimeter were conducted by Stoffregen

et al. (2002) and Schmalholz et al. (2004). Saarenko (1998) measured the dielectric properties in lab scale on clayey and silty soils. He related the imaginary part of the dielectric value to the cation exchange capacity and showed a strong correlation. Nevertheless, radar measurements have strong limitations when applied for clayey soils in the field scale due to the high attenuation.

The combination of electric resistivity and radar is often applied in sandy soils (e.g. Börner, 2000; Binley et al., 2002a; Binley et al., 2002b; Turesson, 2006). Additionally, the phase information obtained from complex conductivity measurements is related to the hydraulic conductivity and the water saturation (e.g. Börner et al., 1996; Ulrich and Slater, 2004; Titov et al., 2004). As a further parameter, ultrasound investigations can provide information about the acoustic properties and the stucture parameters like porosity (Nolen-Hoeksema, 2000). They are also an useful tool for the detection of the transition zone located between fully and partially saturated soils (Schön, 1996). Moreover, Prasad (2003) and Hyndman et al. (2000) tried to establish a relation between seismic velocities and hydraulic conductivity.
HESSD

4, 2659-2681, 2007

Geophysical proxies for soil science investigations

B. Weihnacht and

F. Börner

Title Page

Abstract

Conclusions

Tables

Figures

14

4

Back

Full Screen / Esc

Printer-friendly Version

Interactive Discussion 
Due to the complexity of the ongoing research, one method alone cannot provide the desired geohydraulic parameters with the desired certainty in most cases. For that reason, a combination of geophysical methods like state-of-the-art in borehole investigations becomes more and more common practice also in near surface investigations.

$5 \quad$ This paper is based on a field test conducted to collect data sets on unsaturated and undisturbed soil samples. It is important to demonstrate that the geophysical methods can be applied on this scale and can provide a data set with correct information about hydraulic parameters. Hence, the results were compared to laboratory data. To our knowledge, a similar field data set on unconsolidated rocks in the vadose zone does 10 not exist, so far. The innovation lies in the simultanous application of three geophysical methods on a vertical profile of in-situ samples with high spatial resolution. This is a first step towards a more complex interpretation algorithm.

\section{Material and methods}

\subsection{Test site}

15 The measurements were carried out at the Grenzhof soil physical test site belonging to the University of Heidelberg, Institute for Environmental Physics (Wollschläger and Roth, 2005). The test site is situated at the river Neckar near Heidelberg in the area of alluvial fans (Fig. 2). Various experiments were carried out to investigate the solute transport at this location.

The vertical soil profile at the test site is shown in Fig. 3 . The sandy loam generally found in this area shows an increasing clay content with depth. The uppermost layer $(0-30 \mathrm{~cm})$ is influenced by agricultural use. A dense layer of sandy loam from $90 \mathrm{~cm}$ to $120 \mathrm{~cm}$ separates the above layers from the gravel layers underneath. They are embedded in a clayey matrix which becomes sandier towards deeper areas.

Two parallel outcrops were used to dig off material from both sides to create a walllike measuring object with a thickness of $40 \mathrm{~cm}$. The attenuation of the ultrasonic
HESSD

4, 2659-2681, 2007

\section{Geophysical proxies for soil science investigations \\ B. Weihnacht and \\ F. Börner}

Title Page

Abstract Introduction

Conclusions

Tables

References

Figures

14

4

Back

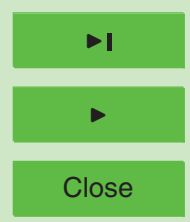

Full Screen / Esc

Printer-friendly Version

Interactive Discussion 
waves was very high, making the registration of transmitted waves through $40 \mathrm{~cm}$ soil impossible with our equipment. Therefore, the thickness had to be reduced to $17 \mathrm{~cm}$, especially for the ultrasonic measurements.

Soil samples of approximately $1 \mathrm{dm}^{3}$ were taken every $15 \mathrm{~cm}$ between $7.5 \mathrm{~cm}$ and $5157.5 \mathrm{~cm}$ of depth for the petrophysical measurements (sample A-K).

\subsection{Petrophysical measurements}

The petrophysical analysis was conducted on the soil samples A-K taken according to Fig. 3. To determine the porosity $\Phi$ the soil material was built in a defined volume $\left(30 \mathrm{~cm}^{3}\right)$ by pouring the material in the container, applying a defined weight on top and 10 shaking it on the vibrating table for $5 \mathrm{~min}$. The porosity obtained is slightly higher than the porosity in the field. The water content was calculated from difference weighting of the wet and the dry sample (dried for $24 \mathrm{~h}$ at $70^{\circ} \mathrm{C}$ ).

The true density $d_{t}$ was measured on the dry samples with the automated equipment AccuPyc 1330 from Micromeritics. Furthermore, the internal surface $S$ was de15 termined nondestructively on a defined sample mass $m$ with the Flowsorb II 2300 from Micromeritics which uses the BET-one-point-method (DIN 66131, DIN 66132).

These data were used to calculate the surface-area-to-porosity ratio $S_{\text {por }}$, which refers to the inverse hydraulic radius of porous media (Pape et al., 1987):

$S_{\text {por }}=\frac{d_{t} S_{m}(1-\Phi)}{\Phi}$ with $S_{m}=\frac{S}{m}$

20 The Cation Exchange Capacity (CEC) was measured with the Mehlich/Bascomb method (DIN ISO 13536). The pore volume related cation exchange capacity $C E C_{\text {por }}$ was obtained from laboratory data of $C E C, \Phi$ and $d_{t}$ (Waxman and Smits, 1968)

$C E C_{\mathrm{por}}=\frac{d_{t} C E C(1-\Phi)}{\Phi}$

Wollschläger and Roth (2005) characterized soil samples taken from a vertical profile

$5 \mathrm{~m}$ away from our outcrop. Layering can be regarded as nearly parallel in this area.
HESSD

4, 2659-2681, 2007

Geophysical proxies for soil science investigations

B. Weihnacht and

F. Börner

Title Page

Abstract

Introduction

Conclusions

Tables

References

Figures

14

4

Back

Close

Full Screen / Esc

Printer-friendly Version

Interactive Discussion

EGU 
Please note that some soil samples were taken at slightly different depths than our samples. For that reason, data of soil characterization was listed only for certain depth intervals in Table 1.

\subsection{Geophysical measurements}

5 The measurements were carried out on a wall-like soil outcrop of unconsolidated rocks. Three geophysical methods were selected for this study: radar, ultrasound and complex conductivity. They provide four independent geophysical proxies: the dielectric constant $\varepsilon_{\text {meas }}$, the compressional wave velocity $v_{p \text {,meas }}$, the specific resistivity $\rho_{\text {meas }}$ and the electrical phase shift $\phi_{\text {meas }}$ as an indicator to the electrical polarizability of the 10 soil. A summary of the methods, devices, spatial increments and errors is listed in Table 2. The errors for radar and ultrasound were estimated from indepentend repeated measurements on the entire vertical profile, whereas the electrical errors result from four repeated measurements without moving the electrodes.

The radar measurements were carried out by two antennas of the surface radar system Ramac/GPR (Malå Geoscience Sweden) with $1 \mathrm{GHz}$ as central frequency. The transmitting antenna was located at one side of the measuring object and the receiving antenna at the other side (Fig. 4).

The ground-penetrating radar system was calibrated with air measurements at the beginning and the end of every experiment to check the drift of the first arrival signal. It was corrected during processing if necessary. After applying a dewow filter to remove the low frequency components of the signal, the first arrival signals for each trace were picked. Knowing the distance $s_{R}$ between the antennas from the geometry of the investigated soil segment, it is possible to calculate $\varepsilon_{\text {meas }}$ in the case of non-magnetic materials (Gerthsen and Vogel,1993):

${ }_{25} \varepsilon_{\text {meas }}=\left(\frac{c t_{R}}{s_{R}}\right)^{2}$,

with $c$ : speed of light $0.3 \mathrm{~m} / \mathrm{ns} ; t_{R}$ : first arrival time of the electromagnetic wave.
HESSD

4, 2659-2681, 2007

Geophysical proxies for soil science investigations

B. Weihnacht and

F. Börner

Title Page

Abstract Introduction

Conclusions

Tables References Figures

14

4

Back

Close

Full Screen / Esc

Printer-friendly Version

Interactive Discussion

EGU 
The ultrasound system from Geotron Electronics uses piezoelectric probes with a main frequency of $30 \mathrm{kHz}$ as transmitter and receiver. Analogous to the radar measurements, the transmitter and the receiver were located on both sides of the investigated object. The signal of the ultrasound wave was registered by a Fluke 99B scopemeter, 5 and the first arrival time $t_{U S}$ was picked for each trace. Ultrasound transmission data were only corrected regarding the offset caused by the measurement device. Knowing the distance between the ultrasound transmitter and the receiver $s_{U S}, v_{p \text {, meas }}$ can be calculated by:

$v_{p, \text { meas }}=\frac{s_{u s}}{t_{u s}}$

10 The electrical measurements were conducted using the device SIP FUCHS II (Radic Research) combined with non-polarizable electrodes for the potential measurement and alternating current injection. The device records the time-series of the electrical voltage $U$ and the electric current $I$. The specific resistivity $\rho_{\text {meas }}$ was calculated for a Wenner array with $a=5 \mathrm{~cm}$ (distance between two adjacent electrodes; Telford et al., 15 1990):

$\rho_{\text {meas }}=2 \pi a \frac{U}{l}$

As a second measuring parameter the phase shift $\phi_{\text {meas }}$ between $U$ and $/$ was determined by signal analysis. The measurements were conducted at a fixed frequency of $0.18 \mathrm{~Hz}$.

\subsection{Fitting procedure}

Petrophysically founded relationships were established to obtain the hydraulic parameters directly from our geophysical proxies by fitting them to the laboratory data manually.

The estimation of the surface-area-to-porosity ratio $S_{p o r}$ which is helpful for evaluating unsaturated flow properties is based on complex electrical measurements. We
HESSD

4, 2659-2681, 2007

Geophysical proxies for soil science investigations

B. Weihnacht and

F. Börner

Title Page

Abstract Introduction

Conclusions

Tables

References

Figures

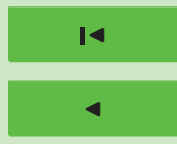

- I

Back

Close

Full Screen / Esc

Printer-friendly Version

Interactive Discussion

EGU 
used the relation

$S_{\text {por }}=a \frac{\tan \left(-\varphi_{\text {meas }}\right)}{\rho_{\text {meas }}}=a \sigma^{\prime \prime}$

HESSD

(Börner et al., 2006) to calculate $S_{\text {por }}$ from the phase $\phi_{\text {meas }}$ and the specific resistivity $\rho_{\text {meas }}$ where $\sigma$ " is the imaginary part of the conductivity and $a$ a fitting parameter. The 5 water saturation $\theta_{w}$ was obtained from the radar measurements. The fitting curve is described by a modified mixing law (Börner, 2000)

$\theta_{w}=\left[\frac{\varepsilon_{\text {meas }}-\varepsilon_{0}}{b}\right]^{n}$

$\varepsilon_{0}$ : dielectric constant of the dry soil, $b, n$ parameters depending on salinity and pore space structure.

The total porosity $\Phi$ was estimated on the basis of the ultrasound data, using the fitting equation suitable for unconsolidated materials (Schön, 1996)

$\Phi=\frac{1-\frac{v_{p, \text { meas }}}{v_{0}}}{C}$

with $v_{0}$ as the compressional wave velocity of the solid phase and $c$ a fitting parameter. $\Phi$ is simply related to the apparent density $d_{a}$ and $d_{t}$ by

$\Phi=1-\frac{d_{a}}{d_{t}}$

Equating Eq. (8) and (9) gives an expression to calculate $d_{t}$ from $v_{p \text {,meas }}$

$d_{a}=\frac{d_{t}(c-1)}{c}-\frac{d_{t}}{v_{0} c} v_{p, \text { meas }}$

A medium true density of $2.65 \mathrm{~g} / \mathrm{cm}^{3}$ was estimated for all data.

\section{4, 2659-2681, 2007}

Geophysical proxies for soil science investigations

B. Weihnacht and

F. Börner

Title Page

Abstract

Conclusions

Tables

14

4

Back

Full Screen / Esc

Printer-friendly Version

Interactive Discussion 
$C E C_{\text {por }}$ was determined from $S_{\text {por }}$ with

$C E C_{\text {por }}=x S_{\text {por }}$

where $x$ refers to the equivalent surface charge density obtained from the laboratory measurements of the internal surface area and the cation exchange capacity.

\subsection{Results}

The summarized geophysical results along the $170 \mathrm{~cm}$ long soil profile of the Grenzhof test site are shown in Fig. 5 . The four curves represent the measured proxies for $\rho_{\text {meas }}$, $\phi_{\text {meas }}, \varepsilon_{\text {meas }}$ and $v_{p \text {,meas }}$. The values for selected depths are given in Table 3.

The geophysical proxies indicate a clear structure of the uppermost $170 \mathrm{~cm}$ of the underground. Four well-defined layers are identified by characteristic combinations of the proxies. The geophysical measurements detect two layers with rather constant values of all parameters: the plough horizon and the dense loamy sand. Other layers (sandy loam, gravel) are characterized by changing proxies caused by vertically changing state parameters.

The zone between $40 \mathrm{~cm}$ and $60 \mathrm{~cm}$ has a low water saturation which causes higher resistivities of about $450 \mathrm{Ohm} \mathrm{m}$ and low dielectric constants between 8 and 9. Generally, increasing phases as well as steady compressional wave velocities are visible in this area. At the lower boundary $(80 \mathrm{~cm}-90 \mathrm{~cm})$ the continuously rising clay content influences all parameters: $\rho_{\text {meas }}$ has a falling trend whereas $\phi_{\text {meas }}, \varepsilon_{\text {meas }}$, and $v_{p \text {,meas }}$ increase.

The gravel layer is characterized by the decreasing clay content in the matrix. This is also reflected by the $\rho_{\text {meas }}$-curve with increasing resistivities and by decreasing $\phi_{\text {meas }}$, $\varepsilon_{\text {meas }}$, and $v_{p \text {,meas }}$ in this area.

As a next step we obtained the soil parameters surface-area-to-porosity ratio $S_{\text {por }}$, water content $\theta_{w}$, porosity $\Phi$, apparent density $d_{a}$ and the porosity-related cation exchange capacity $C E C_{\text {por }}$ directly from the measured geophysical proxies using separate but substantiate petrophysical modells.
HESSD

4, 2659-2681, 2007

Geophysical proxies for soil science investigations

B. Weihnacht and

F. Börner

Title Page

Abstract Introduction

Conclusions

Tables

References

Figures

14

4

Back

Close

Full Screen / Esc

Printer-friendly Version

Interactive Discussion

EGU 
We used Eq. (6) to calculate $S_{\text {por }}$ from the electric proxies. The fitting Parameter a equals $3.77 \times 10^{5} \mathrm{~m} \mathrm{~S}^{-1} \mu \mathrm{m}^{-1}$ for our data set. The radar measurements served to estimate $\theta_{w}$ with $\varepsilon_{0}=4$ for the investigated material and $b=35$ and $n=1.2$ as fitting parameters according to Eq. (7). As a third parameter, $\Phi$ was obtained from Eq. (8)

5 with $v_{0}=5450 \mathrm{~m} / \mathrm{s}$ as the compressional wave velocity of the solid phase and $c=2.35$ as fitting parameters and $d_{a}$ from Eq. (10). A medium true density of $2.65 \mathrm{~g} / \mathrm{cm}^{3}$ was estimated for all data. $C E C_{\text {por }}$ was calculated from Eq. (11) where $x$ equals $0.018 \mathrm{mmol}+/ \mathrm{m}^{2}$.

The petrographical characterization of the soil samples (Table 1) obtained from lab 10 measurements are shown in Fig. 6.

The dense loam layer shows a clear indication in all parameters with $S_{\text {por }}$ up to $200 \mu \mathrm{m}^{-1}, \theta_{w}$ up to 0.35 , lower $\Phi$ below $0.35, d_{a}$ of about $1.75 \mathrm{~g} / \mathrm{cm}^{3}$ and high $C E C_{\text {por }}$ of up to $3800 \mathrm{~mol}+/ \mathrm{m}^{3}$. Otherwise $S_{\text {por }}$ is low $\left(20 \mu \mathrm{m}^{-1}\right), \theta_{w}$ varies between 0.21 and 0.25 , $\Phi$ shows a constant decrease with depth (exept for the gravel), $d_{a}$ lies between $151.60 \mathrm{~g} / \mathrm{cm}^{3}$ and $1.65 \mathrm{~g} / \mathrm{cm}^{3}$ and $C E C_{\text {por }}$ between $100 \mathrm{~mol}+/ \mathrm{m}^{3}$ and $400 \mathrm{~mol}+/ \mathrm{m}^{3}$.

Significant deviations between laboratory and field data of $C E C_{\text {por }}$ are probably caused by the laboratory method destructive to the material.

\section{Discussion and conclusion}

Multi-method geophysical measurements were successfully applied to soil investiga20 tions in the field scale. The presented results and experiences are related to a selected test site with specific soil structure and hydraulic state. Based on multi-method measurements, characteristic data sets of geophysical proxies were detected and related to soil properties.

High resistivities and low dielectric constants indicate low water contents $(40 \mathrm{~cm}-$ $2560 \mathrm{~cm})$. The layer of the dense sandy loam $(90 \mathrm{~cm}-120 \mathrm{~cm})$ is characterized by low resistivities and high dielectric constants caused by high water contents and high com-

HESSD

4, 2659-2681, 2007

Geophysical proxies for soil science investigations

B. Weihnacht and

F. Börner

Title Page

Abstract

Conclusions

Tables

Figures

14

4

Back

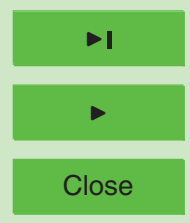

Full Screen / Esc

Printer-friendly Version

Interactive Discussion 
pressional wave velocities due to lower porosities. Within the profile, the highest electrical phase shifts and, hence, high capacitive effects are also found in this layer. They refer to high surface-area-to-porosity ratios or the cation exchange capacity, respectively.

$5 \quad$ We demonstrated that the parameters surface-area-to-porosity ratio, water saturation, apparent density, porosity and the porosity related cation exchange capacity can be calculated directly from geophysical data which gives not only qualitive results but quantitative values of the parameters. Comparing them to laboratory data showed a good agreement for most data. High discrepancies are found only in the layer of the 10 dense sandy loam in the $C E C_{\text {por }}$ curve. This might either be caused by the laboratory method destructive to the material, by heterogeneity and therefore non-representative laboratory probes or by the used model itself. It could be useful to introduce an exponent which would correct the area of misfit. In future work, such a step should be considered and tested if the laboratory method can be excluded as cause for the discrepancies.

The general advantage of the reported method lies in the establishment of simple and petrophysically founded relationships that can be applied for sandy/clayey soils of the same type. Especially for the acoustic properties the fitting results with such a simple relationship are not self-evident and have to be examined carefully with other 20 data.

Water content and surface-area-to-porosity ratio are also well fitted with the established relationships. As a next step they should be compared to other models.

A disadvantage of applying the Eq. (6)-(8), (10) and (11) is the necessity to use fitting parameters which are not constant for all kinds of soil. For that reason it is planned to extend these investigations to a wider variety of soil types, to larger areas and to a broader variety of measurement parameters (e.g. attenuation of the radar and ultrasonic wave). We would also like to use geophysical data gained from the surface to minimize the effort. Additionally, the link between the various geophysical methods with its interpretation will be extended to enhance accuracy and to reduce ambiguity or
HESSD

4, 2659-2681, 2007

Geophysical proxies for soil science investigations

B. Weihnacht and

F. Börner

Title Page

Abstract

Introduction

Conclusions

Tables

References

Figures

14

4

Back

Full Screen / Esc

Printer-friendly Version

Interactive Discussion 
the number of methods.

Acknowledgements. We are grateful to U. Wollschläger and K. Roth for giving us the opportunity for measurements at the Grenzhof test site, the digging arrangements and the provision of soil data. We thank the staff of the Dresden Groundwater Centre for their technical assistance

5 in the petrophysical analysis of soil samples. We also thank an anonymous reviewer for his constructive comments.

This project was funded by the Deutsche Forschungsgemeinschaft (BO 1082/8-3).

\section{References}

Binley, A., Cassiani, G., Middleton, R., and Winship, P.: Vadose zone flow model parameterisation using cross-borehole radar and resistivity imaging, J. Hydrol., 267, 147-159, 2002a.

Binley, A., Winship, P., West, L. J., Pokar, M., and Middleton, R.: Seasonal variation of moisture content in unsaturated sandstone inferred from borehole radar and resistivity profiles, J. Hydrol., 267, 160-172, 2002b.

Börner, F. D., Schopper, J. R., and Weller, A.: Evaluation of transport and storage properties in the soil and groundwater zone from induced polarization measurements, Geophys. Prosp., 44, 583-601, 1996.

Börner, F. D.: Simultaneous determination of water saturation and salinity by combining electric with dielectric measurements during multiphase displacement in sandstones. Proc. 2000 Int. Symp. SCA, Oct. 18-22 2000, Abu Dhabi, VAE, SCA-2000-41, 2000.

20 Börner, F. D.: Complex conductivity measurements, in: Groundwater Geophysics, edited by: Kirsch, R., Springer Berlin, ISBN: 3-540-29383-3, 119-153, 2006.

DIN ISO 13536 (in German): Soil condition; Determination of the potential cation exchange capacity and the exchangeable cations using a $\mathrm{pH}=8,1$ buffered barium chloride solution, 1997.

DIN 66131 (in German): Determination of the specific surface of solids by gas adsorption according to Brunauer, Emmett, Teller (BET), 1993.

DIN 66132 (in German): Determination of the specific surface of solids by nitric adsorption according to Haul, Dümbgen, 1975.

French, H. K., Hardbattle, C., Binley, A., Winship, P., and Jakobsen, L.: Monitoring snowmelt
HESSD

4, 2659-2681, 2007

Geophysical proxies for soil science investigations

B. Weihnacht and

F. Börner

Title Page

Abstract

Introduction

Conclusions

Tables

References

Figures

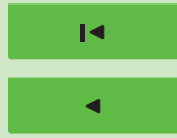

$\rightarrow 1$

Back

Close

Full Screen / Esc

Printer-friendly Version

Interactive Discussion 
induced unsaturated flow and transport using electrical resistivity tomography, J. Hydrol., 267, 273-284, 2002.

Gerthsen C. and Vogel, H.: Physik. 17th edition, Springer Berlin, Heidelberg, New York, London, Paris Tokyo, Hong Kong, Barcelona, Budapest, 1993.

5 Hyndman, D., Harris, J., and Gorelick, S.: Inferring the relation between seismic slowness and hydraulic conductivity in heterogeneous aquifers, Water Resour. Res., 36 , 2121-2132, 2000.

Kemna, A., Vanderborght, J., Kulessa, B., and Vereecken, H.: Imaging and characterisation of subsurface solute transport using electrical resistivity tomography (ERT) and equivalent transport models, J. Hydrol., 267, 125-146, 2002.

Lambot, S., Rhebergen, J., van den Bosch, I., Slob, E. C., and Vanclooster, M.: Measuring the soil water content profile of a sandy soil with an off-ground monostatic ground penetrating radar, Vadose Zone J., 3, 1063-1071, 2004.

Nolen-Hoeksema, R.: Modulus - porosity relations, Gassmann's equations, and the low15 frequency elastic-wave response to fluids, Geophysics, Soc. Expl. Geophys., 65, 1355-1363, 2000.

Pape, H., Riepe, L., and Schopper, J. R.: Theory of self-similar network structures in sedimentary and igneous rocks and their investigation with microscopical and physical methods, J. Microscopy, 148, 121-147, 1987.

Prasad, M.: Velocity-permeability relations within hydraulic units, Geophysics, 68 , 108-117, 2003.

Saarenko, T.: Electrical properties of water in clay and silty soils, J. Appl. Geophys., 40, 73-88, 1998.

Schmalholz, J., Stoffregen, H., Kemna, A., and Yaramanci, U.: Imaging of water content distributions inside a lysimeter using GPR tomography, Vadose Zone Journal, 3, 1106-1115, 2004.

Schön, J. H.: Physical Properties of Rocks, in: Fundamental and principlals of petrophysics, Handbook of Geophysical Exploration, Seismic Exploration, Pergamon Press, Oxford, 1996.

Stoffregen, H., Yaramanci, U., Zenker, T., and Wessolek, G.: Accuracy of soil water content measurements using ground penetrating radar: Comparison of ground penetrating radar and lysimeter data, J. Hydrol., 267, 201-206, 2002.

Telford, W. M., Geldart, L. P., and Sheriff, R. E.: Applied geophysics, Second edition, Camridge University Press, Campridge, 1990.
HESSD

4, 2659-2681, 2007

Geophysical proxies for soil science investigations

B. Weihnacht and

F. Börner

Title Page

Abstract

Introduction

Conclusions

Tables

References

Figures

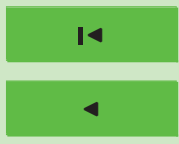

$\rightarrow 1$

Back

Close

Full Screen / Esc

Printer-friendly Version

Interactive Discussion 
Titov, K., Kemna, A., Tarasov, A., and Vereecken, H.: Induced polarization of unsaturated sands determined through time domain measurement, Vadose Zone J., 3, 1160-1168, 2004.

Turesson, A.: Water content and porosity estimated from ground-penetrating radar and resistivity, J. Appl. Geophys., 58, 99-111, 2006.

5 Ulrich, C. and Slater, L. D.: Induced polarization measurements on unsaturated, unconsolidated sands, Geophysics, 69, 762-771, 2004.

Waxman, M. H. and Smits, L. J. M.: Electrical conductivities in oil-bearing shaly sands, Society of Petroleum Engineers Journal, 243, 107-122, 1968.

Wollschläger, U. and Roth, K.: Estimation of temporal changes of volumetric soil water content from ground-penetrating radar reflections, subsurface sensing technologies and applications, 6(2), 207-218, doi:10.1007/s11220-005-0007-y, 2005.

\section{HESSD}

4, 2659-2681, 2007

Geophysical proxies for soil science investigations

B. Weihnacht and

F. Börner

Title Page

Abstract Introduction

Conclusions References

Tables Figures

14

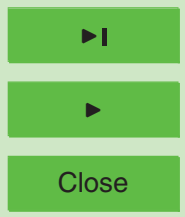

Back

Full Screen / Esc

Printer-friendly Version 


\section{HESSD}

4, 2659-2681, 2007

Geophysical proxies for soil science investigations

Table 1. Petrophysical soil characterization from the test site.

\begin{tabular}{|c|c|c|c|c|c|c|c|}
\hline \multirow[t]{2}{*}{$\begin{array}{l}\text { Depth interval } \\
\text { in } \mathrm{cm}\end{array}$} & \multicolumn{5}{|c|}{ Soil samples A-K } & \multicolumn{2}{|c|}{$\begin{array}{c}\text { Soil samples } \\
\text { (Wollschläger and Roth, 2005) }\end{array}$} \\
\hline & $\begin{array}{l}\mathrm{S}_{m} \text { in } \\
\mathrm{m}^{2} / \mathrm{g}\end{array}$ & $\theta_{w}$ & $\begin{array}{l}\text { CEC in } \\
\mathrm{cmol}+/ \mathrm{kg}\end{array}$ & $\Phi$ & $\begin{array}{l}\rho_{t} \text { in } \\
\mathrm{g} / \mathrm{cm}^{3}\end{array}$ & $\Phi$ & $\begin{array}{l}\text { Medium grain } \\
\text { diameter in } \mathrm{mm}\end{array}$ \\
\hline $0-15$ & 3.83 & 0.15 & 9.8 & 0.44 & 2.61 & 0.39 & \\
\hline $16-32$ & 3.78 & 0.18 & 9.8 & 0.40 & 2.62 & 0.365 & 0.12 \\
\hline $33-46$ & 2.86 & 0.15 & 4.3 & 0.37 & 2.65 & & 0.13 \\
\hline $47-57$ & 2.33 & 0.15 & 3.6 & 0.38 & 2.64 & & \\
\hline $58-70$ & 2.07 & 0.17 & 3.8 & 0.42 & 2.7 & 0.407 & 0.20 \\
\hline $71-85$ & 10.30 & 0.23 & 9.6 & 0.34 & 2.67 & 0.384 & \\
\hline 86-103 & 22.10 & 0.27 & 10.6 & 0.34 & 2.65 & 0.352 & 0.17 \\
\hline 104-122 & 33.60 & 0.32 & 13.2 & 0.35 & 2.64 & 0.362 & 0.21 \\
\hline 123-135 & 9.09 & 0.11 & 5.2 & 0.36 & 2.68 & 0.347 & 0.15 \\
\hline $136-149$ & 5.27 & 0.10 & 10.9 & 0.34 & 2.67 & 0.338 & $2.48^{\star}$ \\
\hline $150-165$ & 4.21 & 0.10 & 3.7 & 0.26 & 2.68 & & $2.42^{\star}$ \\
\hline
\end{tabular}

*approximation (largest sieve $>2 \mathrm{~mm}$ )

B. Weihnacht and

F. Börner

Title Page

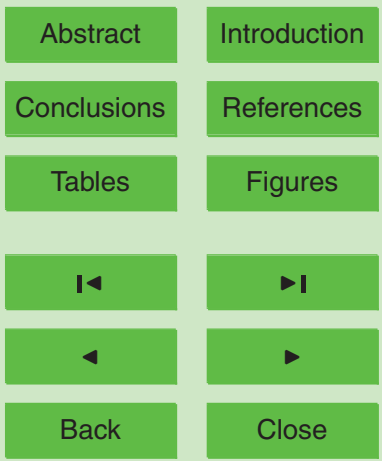

Full Screen / Esc

Printer-friendly Version

Interactive Discussion 


\section{HESSD}

4, 2659-2681, 2007

Geophysical proxies for soil science investigations

Table 2. Summary of the applied geophysical methods.

B. Weihnacht and

F. Börner

\begin{tabular}{|c|c|c|c|c|c|}
\hline Method & $\begin{array}{l}\text { Measurement } \\
\text { parameter }\end{array}$ & $\begin{array}{l}\text { Petrophysical } \\
\text { parameter }\end{array}$ & Device & $\begin{array}{l}\text { Spatial } \\
\text { increment }\end{array}$ & $\begin{array}{l}\text { Error } \\
\text { estimation }\end{array}$ \\
\hline Radar & $t_{R}$ & $\varepsilon_{\text {meas }}$ & $\begin{array}{l}\text { Surface radar } \\
\text { RAMAC/GPR, } 1 \mathrm{GHz}\end{array}$ & $5 \mathrm{~cm}$ & $\varepsilon_{\text {meas }} 9.3 \%$ \\
\hline Ultrasound & $t_{u s}$ & $v_{p, \text { meas }}$ & $\begin{array}{l}\text { USG } 21,30 \mathrm{kHz} \text {-probes } \\
\text { (Geotron Electronics), } \\
\text { Fluke 99B }\end{array}$ & $10 \mathrm{~cm}$ & $v_{p, \text { meas }} 11.0 \%$ \\
\hline $\begin{array}{l}\text { Complex } \\
\text { conductivity }\end{array}$ & $U(t), I(t)$ & $\rho_{\text {meas }}, \phi_{\text {meas }}$ & $\begin{array}{l}\text { SIP FUCHS II (Radic Re- } \\
\text { search), non-polarizable } \\
\text { electrodes, Wenner-array }\end{array}$ & $15 \mathrm{~cm}$ & $\begin{array}{l}\rho_{\text {meas }} 0.1 \% \\
\phi_{\text {meas }} 9.6 \%\end{array}$ \\
\hline
\end{tabular}


Table 3. The values for $\rho_{\text {meas }}, \phi_{\text {meas }}, \varepsilon_{\text {meas }}$ and $v_{p \text {,meas }}$ for selective depths, missing data due to different spatial increments was interpolated.

\begin{tabular}{llllll}
\hline Depth in $\mathrm{cm}$ & Layer & $\rho_{\text {meas }}$ in Ohm ${ }^{*} \mathrm{~m}$ & $\phi_{\text {meas }}$ in rad & $\varepsilon_{\text {meas }}$ & $v_{p, \text { meas }}$ in $\mathrm{m} / \mathrm{s}$ \\
\hline 7.5 & 323 & 0.0126 & 11.5 & 436 \\
22.5 & Plough horizon & 211 & 0.0056 & 12.4 & 429 \\
& & & & & \\
37.5 & & & & & \\
52.5 & & 433 & 0.0104 & 10.1 & 539 \\
67.5 & Sandy loam & 331 & 0.0120 & 8.8 & 528 \\
82.5 & & 115 & 0.0144 & 12.0 & 558 \\
& & & 15.4 & 893 \\
97.5 & \multirow{2}{*}{ Sandy loam, dense } & 32 & 0.0196 & 16.6 & 1076 \\
112.5 & & & 0.0177 & 18.2 & 1040 \\
127.5 & & 152 & 0.0128 & 11.7 & 1065 \\
142.5 & Gravel & 180 & 0.0112 & 10.6 & 1049 \\
157.5 & & 239 & 0.0088 & 11.6 & 356 \\
\hline
\end{tabular}

Geophysical proxies for soil science investigations

B. Weihnacht and

F. Börner

Title Page

Abstract

Introduction

Conclusions

References

Tables

Figures

14

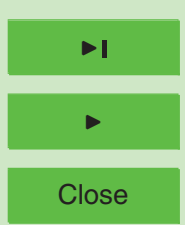

Back

Full Screen / Esc

Printer-friendly Version

Interactive Discussion 


\section{HESSD}

4, 2659-2681, 2007

Geophysical proxies for soil science investigations

B. Weihnacht and F. Börner

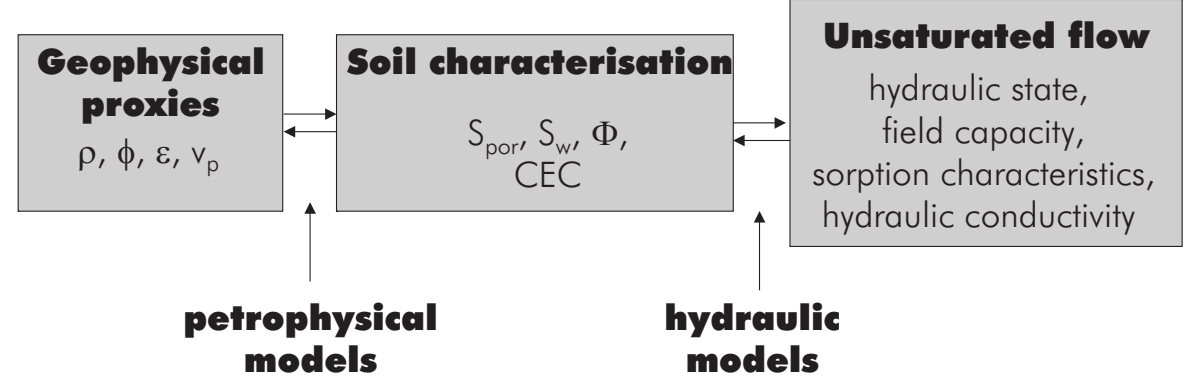

Fig. 1. Interpretation schema for geophysical data.

Title Page

Abstract Introduction

Conclusions References

Tables

Figures

14

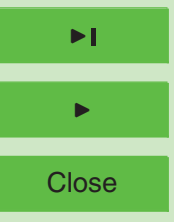

Back

Full Screen / Esc

Printer-friendly Version

Interactive Discussion 


\section{HESSD}

4, 2659-2681, 2007

\section{Geophysical proxies} for soil science

investigations

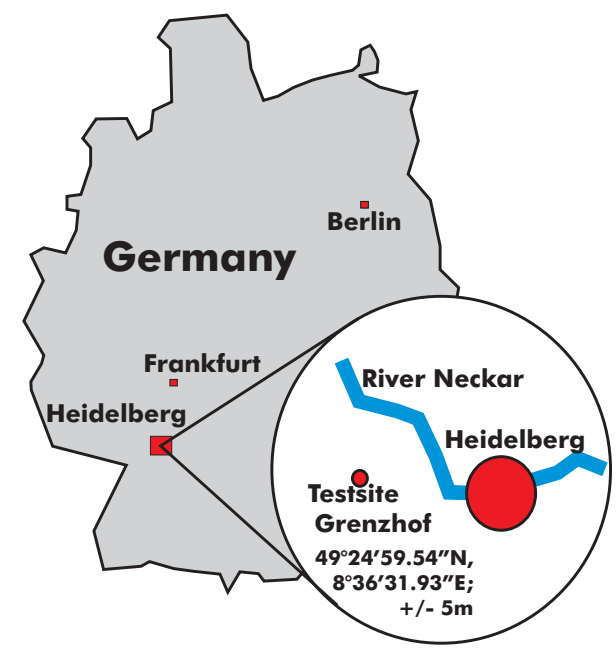

B. Weihnacht and

F. Börner

Title Page

Abstract

Conclusions

Tables

14

4

Back
Introduction

References

Figures

- I

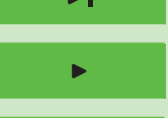

Close

Full Screen / Esc

Printer-friendly Version

Interactive Discussion 


\section{HESSD}

4, 2659-2681, 2007
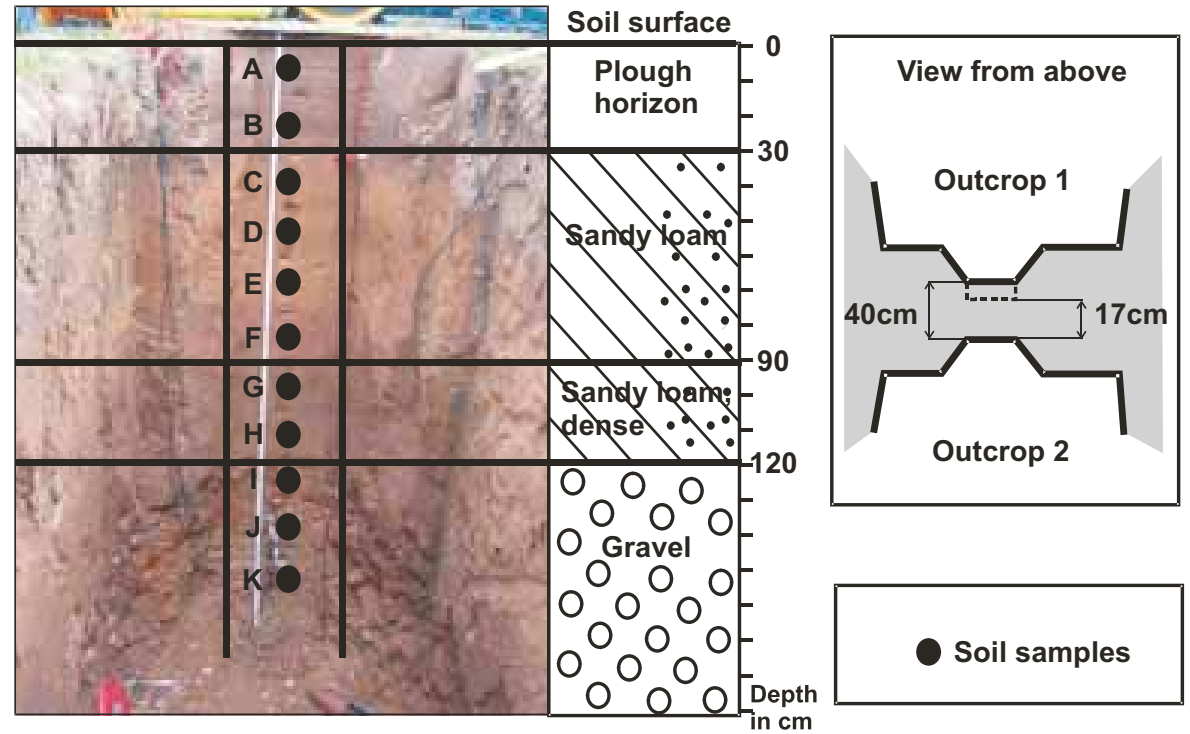

Geophysical proxies for soil science investigations

B. Weihnacht and

F. Börner

Title Page

Abstract

Introduction

Conclusions

References

Tables

Figures

Soil samples

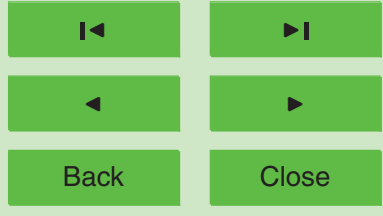

Full Screen / Esc

Printer-friendly Version

Interactive Discussion 


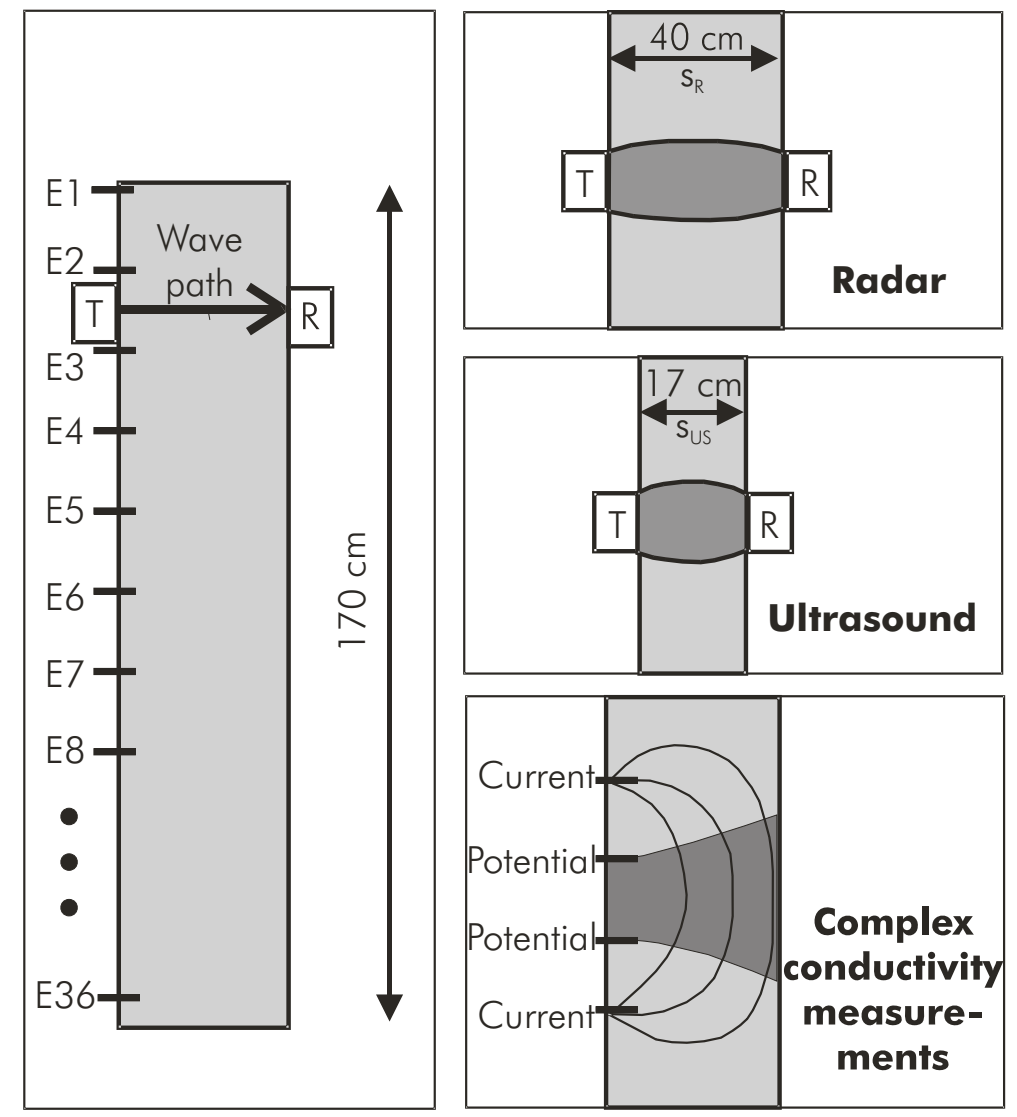

HESSD

4, 2659-2681, 2007

Geophysical proxies for soil science investigations

B. Weihnacht and

F. Börner

Title Page

Abstract

Conclusions

Tables

14

4

Back
Introduction

References

Figures

$\rightarrow$

$>$

Close

Fig. 4. Setup with electrodes E1 to E36 for the complex conductivity measurements, transmitter $(\mathrm{T})$ and receiver $(\mathrm{R})$ for radar and ultrasound measurements; areas of high sensitivity are marked in dark grey.

\section{Full Screen / Esc}

Printer-friendly Version

Interactive Discussion 


\section{HESSD}

4, 2659-2681, 2007

\section{Geophysical proxies} for soil science

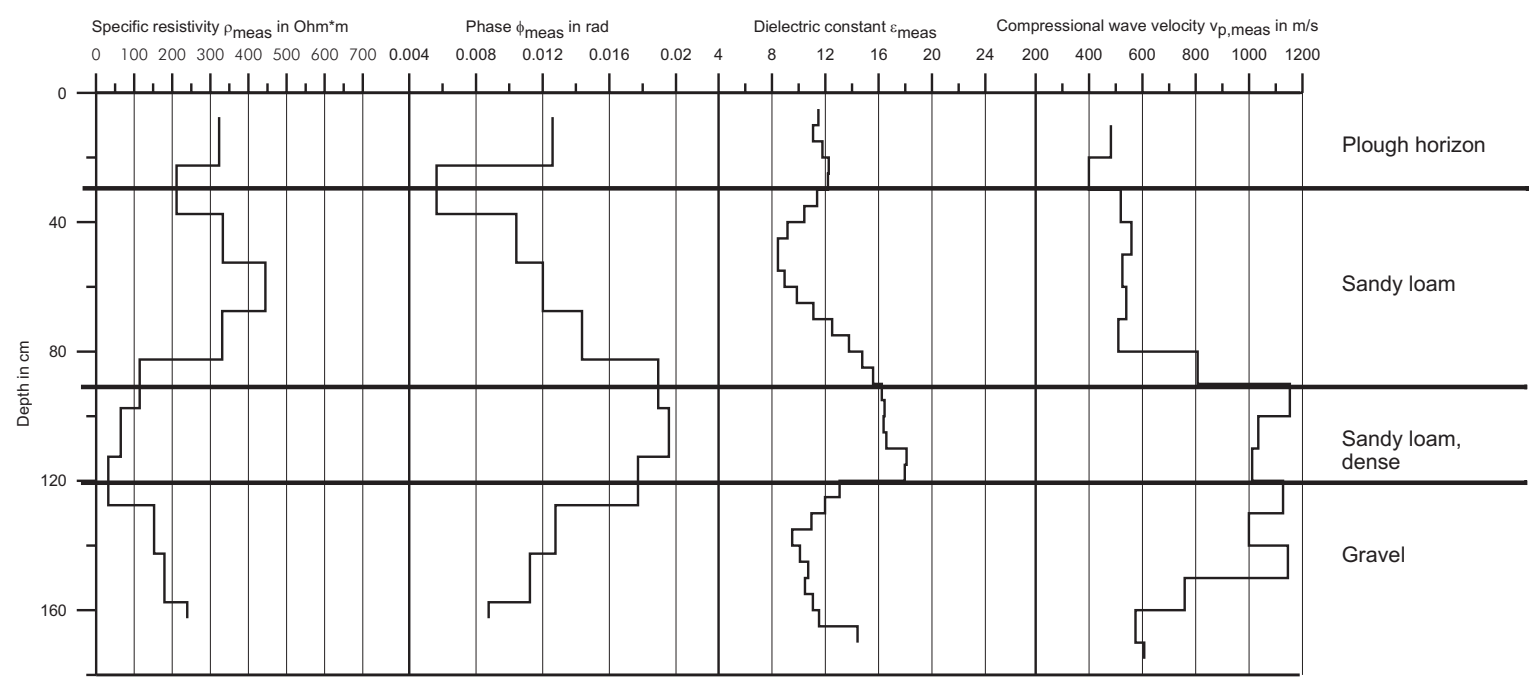
investigations

B. Weihnacht and F. Börner

Title Page

Abstract

Introduction

Conclusions

References

Tables

Figures

14

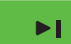

4

Back

Close

Full Screen / Esc

Printer-friendly Version

Interactive Discussion 


\section{HESSD}

4, 2659-2681, 2007

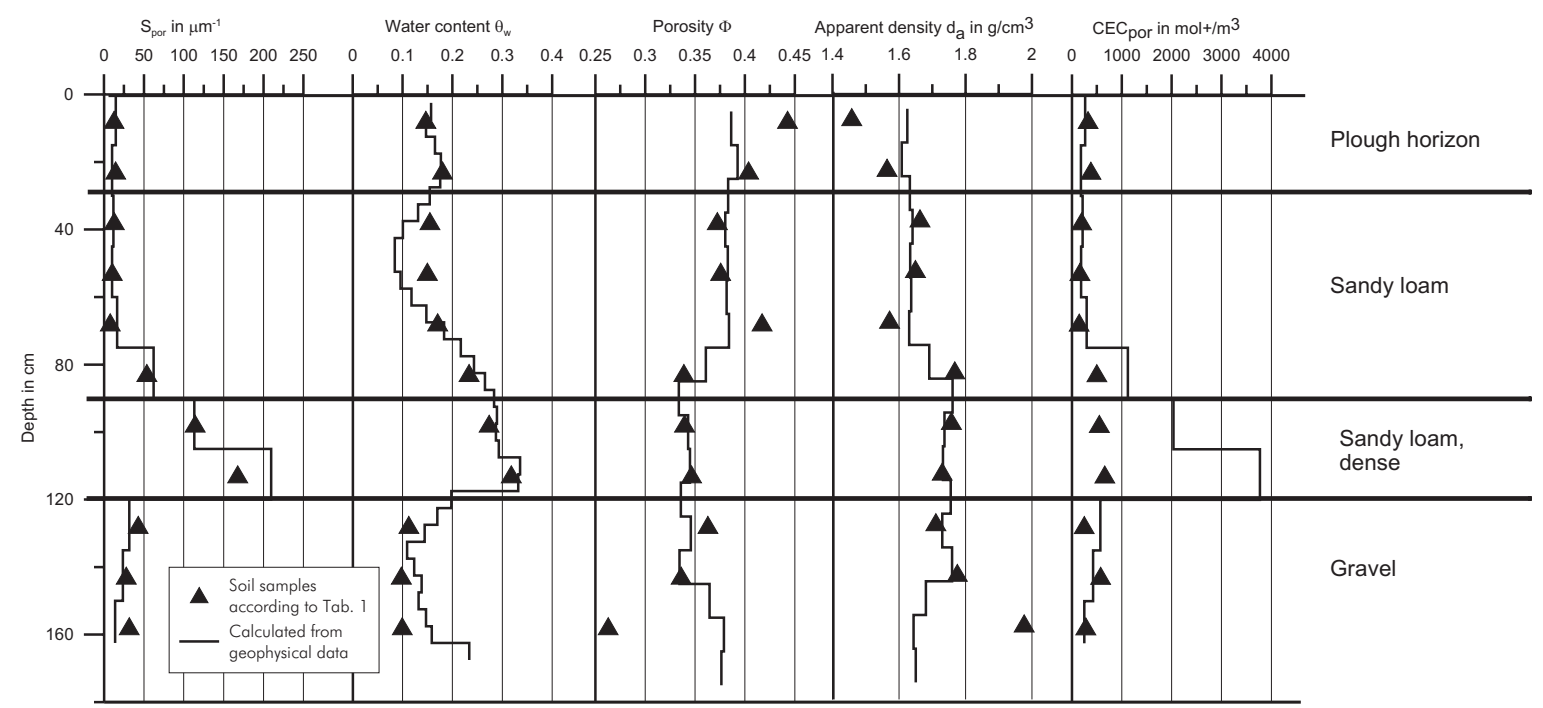

Geophysical proxies for soil science investigations

B. Weihnacht and

F. Börner

\section{Title Page}

Abstract

Introduction

Conclusions

References

Tables

Figures

14

4

Back

Close

Full Screen / Esc

Printer-friendly Version

Interactive Discussion 